\title{
Interpreting the Gospel of MATtheW IN Light OF CURRENT GLOBAL REALITIES: A RESPONSE
}

\begin{abstract}
Author:
Daniel W. Ulrich ${ }^{1,2}$

\section{Affiliations: \\ ${ }^{1}$ Department of $\mathrm{New}$ \\ Testament Studies, \\ Bethany Theological \\ Seminary, USA}

${ }^{2}$ Department of New

Testament Studies, Faculty of Theology, University of

Pretoria, South Africa

\section{Correspondence to:}

Daniel W. Ulrich

e-mail:

ulricda@bethanyseminary.

edu

\section{Postal address:}

Bethany Theological

Seminary, 615 National

Road West, Richmond, IN

47374, USA

\section{Keywords:}

Gospel of Matthew;

Society of Biblical

Literature; hermeneutics;

Matthean texts; Biblical

interpretation in a global

context

\section{Dates:}

Received: 05 Jan. 2009

Accepted: 06 July 2009

Published: 11 Nov. 2009

How to cite this article:

Ulrich, D.W., 2009,

'Interpreting the Gospel

of Matthew in light of

current global realities: A response', HTS Teologiese Studies/Theological Studies 65(1), Art. \#323, 3 pages.

DOI: $10.4102 /$ hts.v65i1.323

\section{This article is available}

at:

http://www.hts.org.za

Note:

Prof. Dr Daniel W.

Ulrich participates in

the research project

'Biblical Theology and

Hermeneutics', directed

by Prof. Dr Andries G.

van Aarde, Honorary

Professor of the Faculty of

Theology at the University of Pretoria.

(C) 2009. The Authors. Licensee: OpenJournals Publishing. This work is licensed under the Creative Commons Attribution License.

\section{ABSTRACT}

This article consists of a response to five papers presented by John Y.H. Yieh (Virginia Theological Seminary), Andries van Aarde (University of Pretoria), Dorothy Jean Weaver (Eastern Mennonite Seminary), Laura Anderson (Graduate Theological Union, Berkeley), and Lidija Novakovic (Baylor University, Waco), presented at the Matthew Section of the Society of Biblical Literature, held in Boston (Massachusetts), 21-25 November 2008. This response focuses on three questions: How can awareness of diverse perspectives or global realities enhance readers' understandings of the Gospel of Matthew? In what ways might the Gospel of Matthew address global problems such as poverty, injustice and violence? To what extent do readers need a hermeneutics of suspicion in order to interpret Matthew responsibly in light of current global realities?

\section{INTRODUCTION}

I am delighted to join Elaine Wainwright in expressing appreciation to all five presenters for their excellent work. In John Yieh's introduction, he expresses hope that hermeneutical reflection can facilitate 'fresh readings of scripture with creative imagination, theological integrity, and ethical responsibility' (p. 1). Those qualities are indeed evident in each paper. Thank you!

Three general questions that I bring to this session are as follows:

- How can awareness of diverse perspectives or global realities enhance readers' understandings of the Gospel of Matthew?

- In what ways might the Gospel of Matthew address global problems such as poverty, injustice and violence?

- To what extent do readers need a hermeneutics of suspicion in order to interpret the Gospel of Matthew responsibly in light of current global realities?

In my response, I plan to ask those questions of/to each paper to the extent that they are applicable. I will also ask other questions that are specific to each paper. My primary goal as a questioner is to prompt further discussion.

\section{JOHN Y.H. YIEH, 'JESUS AS “TEACHER-SAVIOUR" OR "SAVIOUR- TEACHER": READING THE GOSPEL OF MATTHEW IN CHINESE CONTEXTS'}

Yieh's paper gives a fascinating study of the interpretations of the Gospel of Matthew offered by three historic Chinese Christians. Although the featured interpreters differed widely in their theological and political views, Yieh found common ground in their emphasis on Christology and ethics. Each interpreter viewed Jesus' divine sonship as a role more than a title, and each focused on the Sermon on the Mount as a primary source for Jesus' teaching. Yieh's triangulation seems to have located central tendencies in historic Chinese interpretations more reliably than would have been the case if he had presented a single interpretation.

From my very limited perspective, each of the three interpreters had important insights into the Gospel of Matthew, but they were not equally helpful in responding to the social problems of their time or ours. Hong Xiuchuan's use of Matthew is troubling due to his violent reign, his cooperation with European and American colonial powers, and his self-interested legitimisation of his own authority. Even so, Yieh's study raises the question of whether Hong was responding to cues within the narrative that encourage imperialism. Yieh cites Warren Carter's argument that the Gospel of Matthew imitates imperial language in a counter-imperial narrative (Carter 2000:1, 2001:171-179). Taking that argument even further, Joel Willitts (2007:230-231) has claimed that first-century Matthean eschatology included the expectation that Jesus would return to reign with temporal power over a restored Davidic empire. Although I am not yet convinced by Willitts' argument, Carter's is enough to show that Hong was not just dreaming when he took the Gospel of Matthew as a legitimisation for empire.

Yieh presents $\mathrm{Wu}$ Leichuan as the most appealing interpreter of the three. Wu integrated Matthean ethics with Confucian wisdom in an effort to reform and strengthen Chinese society through moral education. Although many of Wu's intellectual peers in Chinese universities opposed Christianity because of its association with Western imperialism, Wu found ways to distinguish Jesus from Western culture and link him with traditional Chinese values. According to Yieh, 'Wu's effort to interpret Jesus and his kingdom of heaven in Chinese terms became one of the earliest and best examples of indigenisation' (p. 4). It appears that $\mathrm{Wu}^{\prime} \mathrm{s}$ approach to interpretation was not a hermeneutics of suspicion, but a hermeneutics of resonance. He selected and emphasised aspects of the narrative that resonated within his cultural context. Wu's fascinating example leads me to ask how a similar interpretive strategy might contextualise the Gospel of Matthew for audiences in China today.

Finally, Nee Tuesheng's reading of Matthew offers an eschatological hope that has more to do with escaping this world than improving it. Even so, I was pleased to see 'Watchman' Nee included in this 
study, partly because I suspect that conservative theologies have been under-represented in previous publications of global perspectives on scripture. My impression is that Nee's interpretations are deeply meaningful to many Christians in China and in other parts of the world.

\section{ANDRIES VAN AARDE, “"FOXES' HOLES AND BIRDS' NESTS" (MT 8:20): A POSTCOLONIAL READING FOR SOUTH AFRICANS FROM THE PERSPECTIVE OF MATTHEW'S ANTI- SOCIETY LANGUAGE}

In contrast to Yieh's historical approach, Andries van Aarde has interpreted the Gospel of Matthew in light of urgent problems in South Africa today. Noting that a vicious cycle of criminality and poverty has led to despair and even death for far too many people, Van Aarde demonstrates that a post-colonial interpretation can address this situation by attending to the Gospel of Matthew's anti-society language (defined as language used to re-order a society's ethical values). After a helpful introduction to postcolonial interpretive theory, Van Aarde draws cautious but illuminating parallels between the situation faced by the poor in today's South Africa and the Roman exploitation of the firstcentury communities addressed by Jesus and Matthew. Matthew 8:20 then becomes a compelling example of anti-society language that speaks on behalf of the poorest in society. According to Van Aarde, the historical Jesus probably used 'the son of man' as a general term for humanity. If so, Jesus' aphorism contrasted the plight of homeless humans with the relative comfort enjoyed by foxes and birds. Decades later, Matthew re-enacted Jesus' anti-society language with a different meaning, since Matthew understood Son of Man as both a self-reference by Jesus and an allusion to Daniel 7. The imperial overtones of Daniel 7 served to empower Matthew's oppressed audience, allowing them to envision a different society in which Jesus, the homeless sufferer, would rule.

Van Aardecalls himself'an active practitioner of the hermeneutics of suspicion' (p. 6). In contrast to Warren Carter, however, he offers a positive assessment of the Gospel of Matthew's imitative use of the language of the basileia or empire. In Van Aarde's view, Matthew creatively co-opts imperial language in order to re-socialise his audience into a 'new, alternative society' (p. 8). Matthew's use of anti-society language thus overcomes the suspicion that Van Aarde typically holds as a critical reader in a post-colonial context.

Van Aarde's positive assessment of Matthew's language also differs from the views of Botswanan post-colonial theologian, Musa Dube. She argues that the Gospel of Matthew contributed to the imperialistic ethos of Christian missions in Africa. Matthew's final commission disregards national boundaries, instructing Jesus' followers to teach all nations without telling them that they should also learn from all nations (Dube 1998:224). Her argument leads me to ask whether aspects of the Gospel of Matthew are problematic in post-colonial South Africa; and, if so, how those aspects should be addressed. Meanwhile, Van Aarde's argument calls for further efforts to show in more concrete terms how contemporary appropriations of Matthew's anti-society language could improve the lives of the poor in South Africa today.

\section{DOROTHY JEAN WEAVER, “THEY DID TO HIM WHATEVER THEY PLEASED"': THE EXERCISE OF POLITICAL POWER WITHIN MATTHEW'S NARRATIVE'}

In contrast to many practitioners of a hermeneutics of suspicion, Dorothy Jean Weaver consistently seeks to read the Gospel of Matthew from the perspective of the implied author. In this paper she finds a direct and revealing analogy between Matthew's portrayal of political abuses and similar realities today. Current news reports of lavish lifestyles, hierarchical commands, public relations initiatives, compromises based on expediency, aggressive campaign rhetoric, lies and deception, murderous conspiracies, show trials, and violent attacks all have counterparts in Matthew's narrative. In our world, such practices often succeed. In Matthew's story-world, however, the unjust exercise of political power is ironically ineffective. The God of Israel simultaneously vindicates Jesus and thwarts the machinations of his enemies.

I found Weaver's paper persuasive, but I began to grow suspicious as she discussed the first-century 'photo-ops' and verbal attacks practiced by Jesus' enemies. Doesn't Matthew portray Jesus as acting in similar ways? Riding into Jerusalem on a donkey and staging a dramatic protest at the temple seem like 'photo-ops' to me. Likewise, the Matthean Jesus launches sharp accusations against his opponents, with the effect that they are silenced and discredited. Although Jesus does not engage in murderous conspiracies or deception, a non-partisan inquiry into Matthew's narrative rhetoric might conclude that Jesus and his opponents are each sharply confrontational, each assert the authority to command, and each engage in actions designed to influence public opinion.

Weaver's conclusion promises a follow-up study that will detail a positive Matthean model for political leadership based on the example of Jesus and characters associated with Jesus. I have learned much from her previous and current work, and I eagerly await her further research on this topic.

\section{LAURA ANDERSON, ‘HEALTHY ECONOMIES OR CAUTIONARY TALES? THE SUB-STRUCTURAL ECONOMIES OF FOUR MATTHEAN HEALING STORIES'}

Weaver and Laura Anderson are both North Americans, but they come from different places theologically. Unlike Weaver, Anderson strongly affirms the need for a hermeneutics of suspicion. She teaches her students to critique all biblical texts, from the most hopeful to the most horrible. Because many of her students have been reluctant to critique the gospels' portraits of Jesus, she is experimenting with the language of economic exchange as an interpretive lens. Perhaps economic transactions are more down-to-earth and thus easier to critique than Christological encomia. In Anderson's view, it is important for Western Christians to begin seeing the textually embedded Jesus as limited and imperfect so that, by analogy, we may begin to recognise our own limitations and to live in more sustainable ways. ' 'Rather than performing Christ triumphant around the world, we may learn to re-enact Jesus the ambiguous within our many contexts' (p. 16).

This is a creative and insightful paper, and I applaud Anderson's goal of teaching Western Christians to recognise our limitations; nevertheless, I wonder whether her pedagogical experiment will achieve that goal. Biblical portrayals of Jesus are sacred to many Christians around the world. If educationally privileged, Western Christians learn that we are competent to judge those portrayals, will the result be greater humility or an even greater tendency to think that our values are supreme?

Anderson's primary critique of the Matthean Jesus in the four healing accounts she analyses is 'his habit of simultaneously healing and excluding' (p. 13). Any act of exclusion is apparently viewed as a fault. Again, I wonder: Should unconditional inclusiveness be the value that trumps all others, or could Matthew be right in teaching other values, such as the need for pistis or trust? I ask this as someone who is also troubled by the text's initially exclusive stance toward the Canaanite woman and her daughter.

1.I have used first-person plural pronouns in this paragraph and the next because count myself within the group described as 'Western Christians.' I do not assume that all readers of this response should be identified in the same way. 


\section{LIDIJA NOVAKOVIC, “"YET EVEN THE DOGS EAT THE CRUMBS THAT FALL FROM THEIR MASTERS' TABLE": MATTHEW'S GOSPEL AND ECONOMIC GLOBALISATION'}

Whereas Anderson uses the language of economic exchange to analyse healing accounts, Lidija Novakovic is concerned with economics in a different way. Novakovic sees in Matthew 'a subversive understanding of power and identity' that could help the church address the widening inequalities brought about by globalisation. Anderson and Novakovic each interpret the Canaanite woman's story, but Novakovic emphasises that the story succeeds in subverting a conventional understanding of spiritual privileges. In various other passages as well, Novakovic finds surprising reversals of hierarchies as well as prophetic calls for the transformation of those inside the church.

Other passages not cited by Novakovic could also have advanced her thesis. For example, the Beatitudes announce dramatic reversals for those who are suffering now (5:3-12). The parable of the vineyard workers (20:1-16) illustrates surprising economic justice from the perspective of the last to be hired. Some Matthean predictions of reversal in the reign of heaven may seem too eschatological to have a direct application to the economic realities of this age.
However, when disciples pray for God's reign to come and God's will to be done on earth as it is in heaven, are we not also being challenged to live our prayers even now? As we discuss Matthew's relevance for the seemingly intractable problems of God's world, further attention to the relationship between eschatology and ethics might be in order.

In conclusion, let me thank the members of the panel again for your wonderfully diverse and insightful papers. I look forward to continued discussions.

\section{REFERENCES}

Carter, W., 2000, Matthew and the margins: A socio-political and religious reading, Orbis, Maryknoll.

Carter, W., 2001, Matthew and empire: Initial explorations, Trinity Press International, Harrisburg.

Dube, M.W., 1998, "Go therefore and make disciples of all nations": A postcolonial perspective on Biblical criticism and pedagogy', in F.F. Segovia \& M.A. Tolbert (eds.), Teaching the Bible: The discourses and politics of Biblical pedagogy, n.p., Orbis, Maryknoll.

Willitts, J., 2007, Matthew's messianic shepherd-king: In search of 'the lost sheep of the house of Israel', Walter de Gruyter, Berlin. 